\title{
Traditional Boy-Boyan Games to Improve Civic Competence of Students
}

\author{
Sari Rejeki Utami, Disman and Sapriya \\ Universitas Pendidikan Indonesia \\ Bandung, Indonesia \\ rejekiutamisarii@student.upi.edu,disman@upi.edu,sapriya@upi.edu
}

\begin{abstract}
The purpose of this paper is explaining the conceptual framework of traditional boy-boyan games which is a traditional game from West Java, as a game in the student's civic competence study in an elementary school. This paper shown the way about traditional boy-boyan games affected into civic knowledge, civic skill, and civic disposition through literature reviews and ongoing research discussions. The implication of this paper is providing a measurement of civic competence.
\end{abstract}

Keywords-elementary school; ethnopedagogy; the civic competence of student in elementary school; traditional games boyboyan; traditional game from West Java

\section{INTRODUCTION}

Citizenship education is inseparable from global influences. These influences directly affected the attitude and students' mindset. For example, the students frequently become liar [1], juvenile delinquency [2], so that is required to develop civic competence overwhelmed civic knowledge, civic skill, and civic disposition, until making grow up the good citizens' character.

The civic competence would be repaired back through the game as learning. Game could be the one solution. A lot of benefit gained in the game as the education sector, starting from stimulates assimilation information students and retention, for motivating students, and improving their motoric [3]. Through games, students learn to participate and communication [4]. In addition, school tuition will be fixed and increases the civic competence by means to communicate and collaborated while game carried out, also the gaming regulations.

A game that could be used into learning had a lot, but in this paper, we using a traditional boy-boyan games. This game could be used as a means learning of medium while playing [58]. The game of boy-boyan it was a game an overhaul of the traditional derived from west java province. The implement of this game in addition for improving student citizenship competence also introduce local wisdom West Java region [9, 10].

The boy-boyan game can improve social skills in early childhood. Finally result had proved that traditional games could be improved social skills. Using of this boy-boyan game as a medium for learning social studies could be increased the learners' activity [11], learning outcomes [12] and social competence [13].

Based on the above explanation, the traditional boy-boyan game was expected to be an innovation in the thematic teaching focus on civic education in achieving citizenship competence, namely civic knowledge, civic skill, and character or civic disposition). The discussion is being conducted at grade fourth of elementary school.

\section{THEORETICAL BASIS}

\section{A. Civic Competence}

Students as citizens should be equipped with some competence or ability as reflected in attitudes, behaviors, and skills. Competence are frequently interpreted as competence is often interpreted as an ability that is reflected in everyday behavior or behavior. As creating good citizens and students which have character, it required adequate citizenship competence.

Civic competences are consisting of three categories: civic knowledge, civic skill, and civic disposition so it can grow up the good citizens' character. These three competencies have been well received and recognized critically. These competences have been developed in various countries, especially in America.

First, civic knowledge. This competence is related to the content or what should be known by the citizens. This competence is manifested in five questions. These questions covering: 1) What is civilian, political, and governmental life? 2) What is the basis of Indonesian political system? 3) How can the government established by the constitution be able to realize the goals, values and principles of democracy in Indonesia? 4) What is Indonesia's relationship with another countries and world affairs? 5) What is the role of citizens in Indonesian democracy? These five questions have been adapted to the situation and conditions in Indonesia. The question will be an indicator of this research. However, only one indicator and those indicators is adapted to the learning materials in grade IV elementary school. The indicator is the role of citizens in Indonesian democracy.

Second, civic skill is a civic competence who apply the knowledge of citizenship that had been mastered. Citizenship skills are civic skills consisting of critical thinking skills; skills 
to evaluate, retrieve and maintain the position; and skills of information participation, and responsibility [14].

Civic skills are developed for the knowledge gained becomes meaningful, because it could be utilized in the life nation and the state. Critical thinking skills are very useful to dealing with political issues. Citizens will first be understanding with the issue, the history, the relevance in the present, as well as a series of specific considerations related to the issues.

The next is skills participation. These skills are categorized into interaction, monitoring, and influences. These participation skills begin to be developed in the earliest classes and continue throughout school [14]. Students in the early classes are taught about skills interacting in a small groups or committees in order to found some information, exchange opinions or compose an action plan appropriate to their maturity level. Student also can learn and listen attentively, question effectively, and manage conflict mediation, compromise, and consensus [14]. While monitoring and influence are learned in the next classes. When students trying to give effect, students can learn through voting. Which is every student participating expresses their opinion [14]. In addition, students can learn through petitioning, speaking, or giving testimony into public bodies. For example, through organizational activities in schools.

Third, civic disposition. This third competence related into the character: personal and public character. A personal character is an original character in every human being. For example: moral responsibility, self-discipline, respectful for the dignity of human beings a whole individual. While the public character is related into the public passion, politeness, respect, the rule of law, critical thinking, and willingness to listen, negotiation and compromised for the success of democracy [14].

The personal and public character as follows:

- Become an independent member of society. This characteristic includes self-awareness to be responsible according to the provisions, none of external compulsion or supervision, accepting responsibility, accepting the consequences of the actions had been made, and fulfilling moral and legal obligations membership in society.

- Fulfilling personal responsibility for citizenship in economics and politics areas. These responsibilities are the responsibility of maintaining oneself, supporting the family, and nurturing, nurturing, and educate the children. Providing information on public issues, voting, paying taxes, serving judges, doing public services, and

- Doing leadership tasks in accordance with their respective talents.

- Earns listening to their opinions, respecting the rights and interests of fellow citizens, and adhering to the principle of majority principle but recognizing minority rights.

- Participate in civic affairs wisely and effectively. These characters cultivating awareness of information before making choices or participating in public debates.

- Developing the functioning of healthy constitutional democracy. This character involves conscious information and attention to public affairs, learning and conferring on the values and principles of the constitution, monitoring the compliance of political leaders and public institutions in judgment, principled, and acting. This character also encourages the state to take steps when changing and giving legal advice is considered unfair and prudent.

From these three competencies, those are four aspects that will be seen as aspects of responsibility, respect for the dignity of each individual (personal character), decency, and willingness to listen, negotiation, and compromise for the success of democracy (public character). The three civic competencies described above are summarized in the table below.

TABLE I. ASPECT AND INDICATOR WILL BE RESEARCH

\begin{tabular}{|l|l|l|}
\hline $\begin{array}{l}\text { Citizenship } \\
\text { Competency }\end{array}$ & Aspect & Indicator \\
\hline $\begin{array}{l}\text { Knowledge of } \\
\text { citizenship }\end{array}$ & $\begin{array}{l}\text { The role of citizens in Indonesian } \\
\text { democracy. }\end{array}$ & Tolerance \\
\hline Citizenship skills & Participation. & Involvement in the community \\
\hline $\begin{array}{l}\text { Character of } \\
\text { Citizenship }\end{array}$ & Responsibility & Social trust \\
\cline { 2 - 3 } & $\begin{array}{l}\text { Respect for the dignity of each } \\
\text { individual human being. }\end{array}$ & Empathy \\
\cline { 2 - 3 } & $\begin{array}{l}\text { Politeness } \\
\text { An positive attitude towards minorities }\end{array}$ \\
\cline { 2 - 3 } & $\begin{array}{l}\text { Willingness to listen, negotiate, and } \\
\text { compromise for the success of } \\
\text { democracy. }\end{array}$ & Politeness \\
& The way of vision or perspective \\
\hline
\end{tabular}


The indicator on the above table is the result of the research of the researcher of the article Bobek, et al (2009) Civic Identity Civic Engagement (CICE) which is one of the measuring tools to measure the identity of good citizens and their compatibility with the presence or absence of good characteristic of citizen [15]. In his research Bobek et al used this instrument for research in eighth grade students. They examined the duties of citizenship, civic skills, and community participation, adult social relationships, peer social relations, and the environment. As well as research Susanto (2015) about the character of citizenship [16]. Research on the competence of citizenship has been done which the result is quite significant $21 \%$.

\section{B. Traditional Game Boy-boyan}

Games for children are many types, one of them is a traditional game. The traditional game is a game that comes from an area that has a fun pattern of simple nature that tends to be what it is. The traditional game has a great value for children in practicing for community life, skill, and dexterity. Traditional games have existed since ancient times and passed down from generation to generation.

Traditional games are nothing but activities governed by a rule of the game which is the derived from the previous generation by humans (children) in order to gaining enjoy [17]. The traditional game is "something (the game) is done by sticking to the norms and customs that existed from generation to generation and can provide a sense of satisfaction or pleasure for the perpetrator" [18]. This understanding is in line with the opinion of Susanti, et al [19] that the traditional game is a game rooted in a culture that develops in an environment.

Meanwhile, the traditional game is very loaded with cultural values that are needed for the development and education of children [20]. The value of togetherness, mutual help, leadership value, is actually a very important cultural value to deal with current conditions. Therefore, the existence of traditional games of children need to be conserved and socialized to the child until whenever.

The use of this traditional game has benefits other than the material is easy to find and also in order to introduce and preserve it. This happens because of the unceasing flow of globalization and High-Tech Science development and the elimination of local wisdom in every region in Indonesia. Therefore, researchers try to use traditional boy-boyan games in order to make students have good citizenship character by fulfilling three characteristics, namely civic intelligence, civic responsibility, and civic participation.

The traditional game used is a game that comes from West Java is boy-boyan. This game actually exists in another areas in Indonesia but uses another name. For example, in the Central Java area boy-boyan known by the name geprek kempung. Although the name is different, but the game system is similar. Geprek means throwing to the target of the fraction of the tile, whereas kempung means throwing toward the child or the opposing player [21]. If in West Nusa Tenggara region there is a game kolo that is almost similar to boy-boyan, but in this game there is a punishment for the losers to lose the team that is holding the winning team [22].
This game is usually done children aged 8-14 years, team (2 team), which consists of 5-6 people or more. This game can be done only boys, women only or mixed.

According to the Directorate of Museum [18] the initial stage or preparation of boy-boys is as follows: preparation is making the boundary of the arena $20 \times 20$ meters and in the middle, there is a $60 \mathrm{~cm}$ diameter circle, at the center of the circle there are 12 kreweng piles, and sweepstakes squads. The lottery winner, for example a team can play first, that is to make kreweng and $\mathrm{b}$ team become guard.

From some of the above explanations it can be concluded that the boy-boyan game has several indicators such as: local wisdom from the Sundanese region, the tools used, the age of the player, the number of players, the place of the game implementation, and the character (mutual respect, sportsmanship, caring, responsibility, tolerance, leader attitude, and good interaction).

Here are the steps of boy-boyan games in West Java based on the experience of researchers who have been validated by experts in the traditional game of West Java:

\section{a. Tools / materials used}

1) Plastic ball made from newspaper bundle and plastic coated and rubber bonded. The ball is quite safe to use, although a hard throw will not make any pain on the player's body.

2) Several pieces of tile fragments that number about 16 pieces.

b. Player. Players are children about 9-10 years old.

c. Number of Participants is more than 3 persons.

d. Place of execution: Field.

e. Step-by-step game

1) Arrange a tile fragment that resembles a tower.

2) Determine the group, the game is done in two groups e.g. group A and group B. After that, both groups will do hompimpa to determine which group is entitled to throw first. The winning group becomes the thrower and the losing group becomes the guard group.

3) The throwing group must throw the ball at the precarious pile, if the pile is successfully destroyed, all the winning group members must run to avoid the throw from the guard group. The throwing group must also reconstruct the crushed tile tower while avoiding the ball throw from the team guard

4) The guard group must try to thwart the throwing group to complete the precarious pile by throwing the ball at the body of all members of the throwing group.

f. The decision of the winner and the loser in the game

1) The thrower group is said to be the winner if the throwing group succeeds in rearranging the precarious fracture before all members of the throwing group are hit by the ball. If won, it is entitled to be a ball thrower again. And guard groups are said to be defeated.

2) Guard groups are said to win if, all members of the throwing group are hit or fail to destroy the precarious heap, and the guard group is entitled to part throw the ball 
towards the pile of precarious fractions. And the throwing group is said to be defeated.

\section{DISCUSSION}

Measurement Instrument of Civic Competence. The research instrument is used as a tool to measure both natural and social phenomena observed [23]. Instruments in this study serves to measure the civic competence of student in class IV. The main task of the institution is to answer the research problem formulation. Therefore, the instrument must be made as well as possible in order to measure accurately and accurately. The instruments used in this research are test, questionnaire, and observation

\section{A. Test}

The test is a series of questions or exercises used to determine the ability of individuals or groups in a particular field, involving skills, knowledge of intelligence, ability or talent [24][25]. The test used in the form of knowledge test in the form of multiple choice regarding the material tolerance. This test is to measure students' citizenship knowledge. Before being used as a test for research, this test should be validated by trial. Then, seen its reliability. If the reliability is high, then a knowledge test can be used for research.

\section{B. Questionnaire}

Questionnaires or questionnaires are widely used techniques to obtain information from the subject. Questionnaires have advantages that are more economical, questions or equipment all apply to the entire subject, and can ensure the subject's secrecy [26]. However, there are drawbacks that the return will be low if the return is via post or other delivery, the questionnaire can only be given to the respondent who can read, and sometimes there is mistake in interpretation so as to make the research result is not accurate [27].

Questionnaire used in closed questionnaire. Closed questionnaire is a questionnaire with the questions asked to the respondent has provided the answer by the researcher, the respondent only chooses answers that are approximately suitable in accordance with his opinion [28]. The questionnaire in this study was prepared based on the adaptation of the CICE instrument used by Bobek et al [15] measuring intelligence, responsibility, and participation and Susanto [16] in his study measurement.

The questionnaire instrument uses a five-point Likert scale. Respondents' answers are a choice of five alternatives, namely:

$$
\begin{array}{ll}
\mathrm{TA} & =\text { Totally Agree } \\
\mathrm{A} & =\text { Agree } \\
\mathrm{N} & =\text { Neutral } \\
\mathrm{D} & =\text { Disagree } \\
\mathrm{TD} & =\text { Totally Disagree }
\end{array}
$$

\begin{tabular}{|c|c|c|c|c|}
\hline Variable & Aspect & Indicator & Question & Kind of Instrument \\
\hline $\begin{array}{l}\text { Civic } \\
\text { knowledge }\end{array}$ & $\begin{array}{l}\text { The role of citizens in } \\
\text { Indonesian democracy. }\end{array}$ & Tolerance & $\begin{array}{l}\text {-Acts that value differences in worship. } \\
\text { - Respect a different friend of religion. } \\
\text { - Making friends without distinguishing religion. } \\
\text { - Not disturbing friends who are worshiping. } \\
\text { - Respecting other religious festivals does not disparage other } \\
\text { religious teachings. } \\
\text { - Receive diversity in the classroom. }\end{array}$ & $\begin{array}{l}\text { Double choice test } \\
\text { instrument }\end{array}$ \\
\hline $\begin{array}{l}\text { Citizenship } \\
\text { skills }\end{array}$ & Participate & $\begin{array}{l}\text { Involvement } \\
\text { in the } \\
\text { community }\end{array}$ & $\begin{array}{l}\text {-Students feel as part of a school and community. } \\
\text {-Students participate in various activities that exist within } \\
\text { the school environment and the community where they live. } \\
\text {-Students often help in school activities. } \\
\text {-Students volunteer in activities at school or in the } \\
\text { community where they live. } \\
\text { - Your students often help his friends. } \\
\text {-Students often help in tempt worship. }\end{array}$ & $\begin{array}{l}\text { Instrument of } \\
\text { competency } \\
\text { measurement of } \\
\text { citizenship aspect in } \\
\text { the form of student } \\
\text { observation sheet. }\end{array}$ \\
\hline \multirow[t]{2}{*}{$\begin{array}{l}\text { Character of } \\
\text { Citizenship }\end{array}$} & \multirow[t]{2}{*}{ Responsibility } & Social trust & $\begin{array}{l}\text {-I feel concerned about the people around my } \\
\text { neighborhood? } \\
\text {-My teacher really cares about me? } \\
\text {-My friends are there when I need them. } \\
\text {-I do my homework. } \\
\text { - Responsible for every action. } \\
\end{array}$ & \multirow[t]{2}{*}{$\begin{array}{l}\text { The instrument of } \\
\text { measuring citizenship } \\
\text { competence aspect in } \\
\text { the form of a } \\
\text { questionnaire using } \\
\text { Likert scale }\end{array}$} \\
\hline & & Empathy & $\begin{array}{l}\text {-I feel pity and pity for the others when they are having } \\
\text { problems, grieving, and getting caught. } \\
\text {-I trying to help solve the problems of others and give and } \\
\text { give donations for those affected. }\end{array}$ & \\
\hline
\end{tabular}

Each answer has the following values:

$\begin{array}{ll}\mathrm{TA} & =5 \\ \mathrm{~A} & =4 \\ \mathrm{~N} & =3 \\ \mathrm{D} & =2 \\ \mathrm{TD} & =1\end{array}$

TABLE II. QUESTIONNAIRE INSTRUMENT 
TABLE II. Cont.

\begin{tabular}{|c|c|c|c|c|}
\hline Variable & Aspect & Indicator & Question & Kind of Instrument \\
\hline & $\begin{array}{l}\text { Respect for the dignity of } \\
\text { each individual human } \\
\text { being. }\end{array}$ & $\begin{array}{l}\text { A positive } \\
\text { attitude } \\
\text { towards } \\
\text { minorities }\end{array}$ & $\begin{array}{l}\text {-I would argue that all ethnic groups in Indonesia should } \\
\text { have equal opportunity to get education, decent work, and } \\
\text { occupy political office in government. }\end{array}$ & \\
\hline & Politeness & Politeness & $\begin{array}{l}\text {-I am always polite in stopping others when expressing } \\
\text { opinions. } \\
\text {-I can always be patient to wait for my turn to express my } \\
\text { opinion. }\end{array}$ & \\
\hline & $\begin{array}{l}\text { Willingness to listen, } \\
\text { negotiate, and compromise } \\
\text { for the success of } \\
\text { democracy }\end{array}$ & $\begin{array}{l}\text { Leadership } \\
\text { attitude in } \\
\text { groups }\end{array}$ & $\begin{array}{l}\text {-I'm trying to learn to work together in groups to do } \\
\text { activities. } \\
\text { - I am responsible for implementing joint decisions in } \\
\text { organizing even if the decision is different from my } \\
\text { opinion. }\end{array}$ & \\
\hline & & $\begin{array}{l}\text { A perspective } \\
\text { or perspective }\end{array}$ & $\begin{array}{l}\text {-I always understand the thoughts of others when they } \\
\text { express opinions and do something. } \\
\text { - I try to consider the feelings of others, before I decide to } \\
\text { say or do what to them. }\end{array}$ & \\
\hline
\end{tabular}

\section{CONCLUSION}

This paper was made earlier for further research on citizenship competence using traditional boy-boyan games. We suggest this theory could be developed in accordance with the situation and conditions of students to be studied. From this literary study, it shows that the traditional boyboyan game can be used as a learning game.

\section{REFERENCES}

[1] F. Maa, "To Lie or Not to Lie? The Influence of Parenting and Theory of Mind Understanding on Three Years Old Children's Honesty", Journal of Moral Education, 2015.

[2] T. Lickona, Educating for Character: How Our Schools can Teach Respect and Responsibility. New York: Bantam Books, 1991.

[3] E. Koh, Teacher Perceptions of Games in Singapore Schools. Simulation \& Gaming, 43 (1), pp 51-66, 2012.

[4] I. Iacovides, The Gaming Involvement and Informal Learning Framework. Simulation \& Gaming, 45 (4-5) pp 611-626, 2014.

[5] E.C.A. Ardiansyah, Pengaruh Permainan Tradisional Terhadap Peningkatan Keterampilan Sosial Anak Prasekolah, 2012.

[6] C.C.D. Anggraini and M.F.A. Untarai, "Keefektifan Permainan Boyboyan terhadap Hasil Belajar Tema "Diriku" Siswa Kelas I SD", Mimbar Sekolah Dasar, 1, pp 92-98, 2014.

[7] Y.T. Saleh, "Model Permainan Tradisional "Boy-boyan" untuk Meningkatkan Perkembangan Sosial Anak SD”, ELSE (Elementary School Education Journal): Jurnal Pendidikan dan Pembelajaran Sekolah Dasar, 1, 2017.

[8] S. Hayati, "Effect of Traditional Games, Learning Motivation And Learning Style On Childhoods Gross Motor Skills", International Journal of Education and Research, 5, 7, 2017.

[9] D. Hidayat, "Permainan Tradisional dan Kearifan LokalKampung Dukuh Garut Selatan Jawa Barat", Jurnal Academica Fisip Untad, 2013.

[10] B.Y. Wulansari, "Pelestarian Seni Budaya dn Permainan Tradisional Melalui Tema Kearifan Lokal dalam Kurikulum Pendidikan Anak Usia Dini”, Jurnal Indria: Jurnal Ilmiah Pendidikan Prasekolah dan Sekolah Awal, 2, (1), 2017.

[11] T. Wahyuni, Penggunaan Media Boy-Boyan pada Pembelajaran IPS untuk Meningkatkan Aktivitas Belajar Peserta Didik Kelas V di SDN Arjosari 02 Kecamatan Kalipare Kabupaten Malang, 2015.
[12] F. Wulandari, "Permainan Tradisional "Gaprek Kempung" sebagai Media Pembelajaran pada Mata Pelajaran Ekonomi Kelas VII", Jurnal Pendidikan: Teori, Penelitian, dan Pengembangan, 2017.

[13] M. Marzoan and H. Hamidi, "Permainan Tradisional sebagai Kegiatan Ekstrakurikuler untuk Meningkatkan Kompetensi Sosial Siswa", Journal An-Nafs: Kajian Penelitian Psikologi, 2, (1), pp 4255, 2017.

[14] M.S. Branson, The Role of Civic Education. Calabasas. CEE, 1999.

[15] D. Bobek, J. Zaff, Y. Li and R.M. Lerner, "Cognitive , emotional, and behavioral components of civic action: Towards an integrated measure of civic engagement", Journal of Applied Developmental Psychology, 30(5), pp 615-627, 2009.

[16] E. Susanto, Pengaruh Pembelajaran, Habituasi, dan Ekstrakurikuler terhadap Pengembangan Civic Disposition siswa di sma negeri sekota Bandar Lampung. Bandung: Pascasarjana, 2015.

[17] I.H. Misbach, Peran Permainan Tradisional yang Bermuatan Edukatif dalam Menyumbang Pembentukan Karakter dan Identitas Bangsa. Bandung, 2007.

[18] Direktorat Permuseuman, Permainan Tradisional Indonesia. Jakarta: Proyek Pembinaan Permuseuman, 1998.

[19] S. Susanti, "Pengaruh Permainan Tradisional terhadap Kompetensi Interpersonal dengan Teman Sebaya pada Siswa SD", Jurnal Penelitiandi Universitas Diponegoro, 2012.

[20] E. Purwaningsih, "Permainan Tradisional Anak: Salah Satu Khasanah yang Perlu Dilestarikan”, Jantra: Jurnal Sejarah dan Budaya, 1, 2006.

[21] Departemen Pendidikan dan Kebudayaan, Permainan Rakyat Jawa Tengah. Jakarta: Depdikbud, 1983b.

[22] Departemen Pendidikan dan Kebudayaan. (1982a) Permainan Rakyat Nusa Tenggara Barat. Jakarta: Depdikbud.

[23] S. Sugiyono, Metode Penelitian Pendidikan (Pendekatan Kuantitatif, Kualitatif, dan R\&D). Bandung: Alfabeta, 2007.

[24] R. Riduwan, Belajar Mudah Penelitian untuk Guru-Karyawan dan Peneliti Pemula. Bandung: Alfabeta, 2012.

[25] S. Arikunto, Prosedur Penelitian: Suatu Pendekatan Praktik. Jakarta: PT. Rineka Cipta, 2013.

[26] J.H. McMillan and S. Scumacher, Research in Education. Edisi terjemahan. New York: Addison Wesley Longman. Inc., 1997.

[27] S. Siregar, Metode Penelitian Kuantitatif Dilengkapi Perbandingan Perhitungan Manual \& SPSS. Edisi Pertama. Jakarta: Kencana, 2013.

[28] E. Danial, Metode Penulisan Karya Ilmiah. Bandung: Laboratorium Pendidikan Kewarganegaraan Universitas Pendidikan Indonesia, 2009. 